\title{
The Influence of New Media on College Students' Values and College Education Countermeasures
}

\author{
Hongxiang Zhao \\ School of economics and management, Shenyang University of Aeronautics and Astronautics
}

\begin{abstract}
-in the continuous development and progress of modern society, under the new media as the spread of emerging power, to a people's spreading news and some spiritual power. But the development of new media, its disadvantages are also gradually revealed. For college students, life cannot leave the new media, and are used every day in the qq, for example, wechat, weibo, news or video. This shows the strong penetration of new media in modern life. But in the university students' life like high school and junior high school is no longer drab, but full of diverse colors. University is the students into a transition period of society, some understanding of the social concept can form, the outlook on life, world outlook and judgments would also be affected or change. During the period of university, even if the school has a strong academic atmosphere, also cannot stop seepage factors in college students' life, one of the new media is a kind of very typical. The spread of the rapid development of the new media as well as its rich content affect college students' world outlook, outlook on life, values, the formation of sense. To actively spread positive energy at the same time, also brought negative energy.
\end{abstract}

Keywords-the spread of new media; university students; impact

\section{INTRODUCTION}

In the backdrop of the rapid development of modern society, the new media widely infiltration among the college students' life. Open the QQ, you can see in the QQ space news, articles, and QQ Wechat students in everyday use, information spread very quickly, Weibo is good and evil people mixed up, positive energy and negative energy always coexist, these are all college students participation from day to day. Because the new media has spread is wide and its usage without threshold and limit freedom of speech is unrestricted, has the very high timeliness, equality, and the characteristics of the interactivity and so on, the existence of the long and profound influence on college students' values, outlook on life, the sense of the formation, change and development. In order to allow students to healthy growth, we need to know to the development of new media law, propagation law and its limitation content, combined with the actual situation of the college students to use new media, in-depth understanding of the influence of new media on college students, infiltration degree and its influence to the college students, which is, to the external environment of the university students to create a positive energy, teach students to form correct, positive, healthy values, judgments, the outlook on life, form good political quality, this is the university of the problems facing in improving students' quality.

One. the concept and characteristics of new media

Because of much new media form in the modern society to its definition varies wildly. But I think, now that is called "new media" is compared with the "old media". New media is the traditional media such as newspaper, radio, television after the development of new media forms, including network media, mobile phones, digital TV and other media. New media is a broad concept, using the digital technology, network technology, through the Internet, broadband local area network (LAN), wireless communication network, satellite channels, such as for the spread of digital media. New media is able to mass media provide personalized content at the same time, is a communicators and recipients synthesize pairs, such as communication, while countless communicators to each other can be personalized communication media.

Mention are the distinctive features of the new media is its interactivity and timeliness. In terms of timeliness, happen anytime and anywhere can be quickly spread through the new media, Weibo and so on, for example, when people see is often happened only a short period of time, new media, very fast determines its timeliness. New media and interactivity is refers to the Weibo, Wechat, BBS, blog, communication on a personal point of view of people, and so on. A release of information is often unimportant, the key is to view and attitude of this event, and people for the exchange of views on the matter. Is different from traditional media and new media is the medium used to obtain the information, but interpersonal communication tool to comment on something. Of course, everyone is itself information source, can release news and information, so the new media is also an important way for people to share life.

But the new media users, anyone can use, anyone can freedom of speech, this suggests that the good and evil people mixed up in the new media, also can have bad intention of using new media to spread bad information, so in daily life, we will find in the network is filled with a lot of bad information, even some people on the network platform some unhealthy ideas incorrect comments. But if some people encountered difficulties, you can through the new media for help, because of the new media transmission range, speed, so often can help recipients. Something positive energy through new media exposure, can quickly spread positive energy. So, so is the new media has two sides, the impact of it also has two sides. 
Second, the new media's impact on college students' values

Rise a word "bow" crowd, now is the time in play phone. Mobile phone is one of the important media, new media, because the cell phone use is convenient, people often through the phone to get information on the network platform, for now the rates of college students is even more so. Rates after the university student the thought is agile, very interested in new things, and life without mobile phones, inseparable from the new media, brush every day in weibo, brush a circle of friends, etc., so now the college students is the main force of the use of new media, as well as a number of people affected by the new media's biggest, because, college students often do not have a mature of the firm's ability to judge right and wrong, values, world view and also in the form of, easy to receive the influence of external factors.

\section{NEW MEDIA THE POSITIVE INFLUENCE ON COLLEGE STUDENTS' VALUES}

\section{A. New media is beneficial to the development of the college students' political view.}

New media to the cultivation of the college students' political theory mainly now spread of our country's important news. New media has a wide spread, spread very fast, the characteristics of the mode of transmission is very diverse, so the new media to current events happened in our country, the country's leaders to make decisions and so on with fast speed and multiple ways for college students to see. Such as college students can see through with words and images of news, also can see from the video web site or video software. College students can not be alienated from society, cannot be blindly learning person, but to understand current affairs, political hot spot, etc. Through new media college students can understand the Chinese government in the natural hazards occur react fast and correct guidance, our understanding to Syria war quickly moving overseas Chinese at breakneck speed, learned that in our country up a process to make the policy, understand the new progress of the socialist construction of our country, to understand the new changes of our country. New media to the spread of the national policy to make college students takes the correct ideological and political course, and loving socialism, love their motherland, cultivating their strong patriotic emotion and pride, enable students to firm went under the leadership of the party. So the new media is beneficial to the development of the college students' political view.

\section{B. New media is beneficial to the development of the consciousness of college students.}

The generation of new media to the world into a big circle, like a global village. Because of the emergence of new media to spread the information around the world. College students' use of multimedia can see but the world is no longer just about China, it certainly broadened their horizons and freed their consciousness. New media is a college student don't do "tunnel vision" but look the important media of the world. For example, university students can be learned through new media to know their professional development abroad, research situation, can broaden their knowledge, broaden the study field of vision, so that new ideas to develop college students a lot of new ideas. Through new media, to prepare college students for its own study, such as learning the local humanities customs, local language and so on. New media, of course, can not only make our state of the college students to know the outside world can also to show the world China's college students' elegant appearance as well as research results, and so on.

\section{New media is beneficial to the development of the college students' social responsibility.}

University is one of the students into the social transition period, during this transition period, require university students learned knowledge is not only for work after graduation, also requires students to know society, early early can adapt to society, to cultivate students sense of responsibility to the society, more important is to make the university to participate in the society. The new media as the medium of communication for college students to participate in social opportunities. On new media platform, students can express their views on some things in society and insights and even try to put forward a solution. For example, some people turn on in the face of new media, college students often after verification information, collecting in the school organization, blood donation, donated blood stem cells, etc., white is out of a force. During the National People's Congress, and college students actively participate in the discussion, put forward their views and opinions. College students can actively participate in some hot topic of discussion, such as the recently frequent lost in female college students, etc., after the understanding, through the organization some lectures, or some articles to help the girls around the alert, pay attention to safety. New media for college students to participate in the society provides a good platform.

\section{THE NEGATIVE IMPACT OF NEW MEDIA ON COLLEGE STUDENTS' VALUES}

\section{A. The new media impact on college students' values standard.}

The spread of new media content tend to have a positive active content is often accompanied with the negative content, so the formation of new media on college students' values is a "double-edged sword". In new media is also in the process of globalization, college students can timely understand the globalization trend and a lot of different values, world view and sense. But in the process of the spread of new media, there are always some bad information transmission, such as money worship and so on the wrong ideas, can severely erode the values of college students, cause serious negative effect. Even there will be a hostile political power advocates college students on a path to the wrong political thought. For example, the spread of falun gong, it travels through the various new media means, harm people's physical and mental health. Because college students after the rates for most things carry with freshness and accept ability strong, right from wrong ability is limited, it is easy to get bad information. 


\section{B. The attenuation of the new media on college students' moral standards.}

Is an important characteristic of the new media users have no threshold, this creates the use of good and evil people mixed up the crowd, and release information on new media, people are free to comment, and these comments also often there are no moral. Because some people have nothing but indifferent, in order to reflect individual character, attract attention, often can give no human nature, and some even moral upside down comments, and college students are easy to be affected. The loss of morality, moral standards, in violation of the social mainstream values of comments are likely to bring bad "role model" to the college students, because it is anonymous comments, college students in order to be different, are more likely to follow suit, over time, will be a vicious impact on college students' values.

\section{New media to complete the expansion of the college students' self-consciousness.}

Rates after college students pursue different, the pursuit of individual character make public, and the new media gave the students a full display platform. College students on these platforms is also like a duck to water, such as college students role Weibo send video, articles, in Wechat, QQ to write some words on the paragraph express their unique ideas and so on. The tool for college students to show their to provide a means, but due to the college students lack self-discipline, excessive pursuit of make public individual character, self-awareness bloated, caused the college students in some articles on the network of wrong idea was a lot of netizens. This spirit of order and network caused the damage.

\section{Second, under the condition of new media on college students' values education in colleges and universities.}

Faced with the good and evil people mixed up Internet users, have different mental strength, how to let college students in the use of new media in the process of correct thought way and the correct outlook on life, world outlook, the values are very important subject. In the face of this phenomenon, we should actively face, apply the appropriate countermeasures for social culture has the responsibility to the nation's successor.

\section{A FIRM POLITICAL POSITION AND OPINION}

Although college students in the face of the new media in the information may not have enough ability to identify, but in the direction of ideological and political course, the school can make students have discrimination by learning. Opened in the university's "introduction to MAO zedong thought and theory system of socialism with Chinese characteristics", "thought morals tutelage and legal foundation", "the modern history of China is just" course will guide students to adhere to the leadership of the party, such as popular party, adhere to the socialist course, maintain the correctness of the political stance.

\section{THE VALUES OF INNOVATION EDUCATION METHOD}

Must first adhere to the people-centered, education to college students' daily life. During the values education of college students because of pure thought political lesson is boring, so will thought political lesson of the theory of combined with extracurricular activities practices. Adhere to the student-centered classroom topic, as far as possible avoid empty teacher constantly preaching. Innovation of science and technology, establish good communication system. Teachers should also keep up with the pace of the new media, with students using Weibo, Wechat etc. New media, so that can find problems in time, some students, dynamic moment can also learn about the student's thought.

We should cultivate the students the correct values, teach students to use the face of new media, and negative.

\section{REFERENCE}

[1] Wang Jianfei TV media's influence on college students' values and its countermeasure research [D]. Southwest university, 2013.

[2] Lin Chao. New media's influence on college students' ideological and political education in colleges and universities and the countermeasures [D]. Fujian normal university, 2013.

[3] Yang Xueping. Network public opinion impact on university students' values and countermeasure research [D]. Wuhan engineering university, 2013.

[4] Shi Chunhong. New media's influence on college students and education countermeasures research [D]. Xi 'an university of science and technology, 2013.

[5] Dai Jing. The influence of the mobile phone media on college students' ideological and political education and countermeasures research [D]. Yangzhou university, 2013.

[6] Chen Jia. Network culture's influence on the contemporary college students' values and education guidance countermeasure research [D]. Southwest university, 2013.

[7] Peng Lin. New media's impact on college students' moral education and countermeasures research [D]. Hebei economic and trade university, 2014. 